\title{
Morphometrics and seasonal occurrence of metacestodes of Neogryporhynchus cheilancristrotus (Cyclophyllidea: Dilepididae) in the blue bream (Abramis ballerus) from the Oder River (Germany/Poland)
}

\author{
Michael Pietrock ${ }^{1}$ and Tomáš Scholz ${ }^{2}$ \\ ${ }^{1}$ Institute of Freshwater Ecology and Inland Fisheries Berlin, Müggelseedamm 310, 12587 Berlin, Germany; \\ ${ }^{2}$ Institute of Parasitology, Academy of Sciences of the Czech Republic, Branišovská 31, 37005 České Budějovice, Czech \\ Republic
}

Key words: Neogryporhynchus cheilancristrotus, Dilepididae, morphometrics, seasonal occurrence, Abramis ballerus, Oder River

\begin{abstract}
From May 1993 to April 1995, the seasonal occurrence of metacestodes of Neogryporhynchus cheilancristrotus (Wedl, 1855) (Cyclophyllidea: Dilepididae) in its second intermediate host, the blue bream Abramis ballerus (L.) was studied monthly in the Oder River on the borders of Germany and Poland. Based on the parasite specimens found, detailed data on their morphometrics are presented. The metacestodes occurred in the blue bream intestine throughout the year (overall prevalence $27 \%$ and intensity 1-56 (mean 4.8) metacestodes per infected fish). Increased prevalences and mean intensities of infection were noted from March to June and November to December indicating that spring, late autumn and early winter are the main periods of new infections.
\end{abstract}

Metacestodes of the dilepidid tapeworm Neogryporhynchus cheilancristrotus (Wedl, 1855) inhabit the digestive tract of freshwater fishes, particularly cyprinids, in the Palaearctic region (Bona 1975, Chubb et al. 1987, Dubinina 1987, Scholz 1989). The life cycle of this cyclophyllidean cestode involves two intermediate hosts: a cyclopid copepod such as Mesocyclops oithonoides, in the body cavity of which a metacestode named cercoscolex develops (Jarecka 1970), and a fish in the intestine of which metacestodes named plerocerci occur. Herons such as Ardea cinerea, A. purpurea, Nycticorax nycticorax and Botaurus stellaris serve as final hosts (Bona 1975).

Although dilepidid metacestodes from the intestine of freshwater fishes have been known for more than 160 years since the species Gryporhynchus pusillus Nordmann, 1832 was described, there is great confusion concerning their taxonomy and nomenclature (see Baer and Bona 1960, Bona 1975). These authors revised type and voucher specimens of dilepidid larvae from freshwater fishes and concluded that the taxon Gryporhynchus pusillus was inadequately described, and it cannot be considered identical with certainty with larvae described under this name by subsequent authors (see Bona 1975 for review). The latter larvae were found to be conspecific with the species Taenia cheilancristrota described as adults from fish-eating birds by Wedl (1855). According to Baer and Bona (1960), Wedl's description was the first to provide sufficient morphological data to characterise the taxon. Because of the doubtful status of the type species of the genus Gryporhynchus Nordmann, 1832, G. pusillus, Baer and Bona (1960) proposed a new genus, Neogryporhynchus, to accommodate Taenia cheilancristrota (= Neogryporhynchus cheilancristrotus (Wedl, 1855)).

The conclusions of Baer and Bona (1960) and Bona (1975) have generally been accepted and the name Neogryporhynchus cheilancristrotus has been widely used (Jarecka 1975, Chubb 1982, Chubb et al. 1987, Dubinina 1987, Scholz 1989). However, there still persists some confusion in the taxonomy of dilepidid larvae and different names such as $N$. cheilancristrotus, G. pusillus or G. macropeos appear in the literature (see Bona 1975, Dubinina 1987, Scholz 1989). In addition, distinct differences in the size of rostellar hooks, being a major taxonomic feature of dilepidid tapeworms, have been reported by individual authors (Dubinina 1987, Scholz 1989, Pietrock 1998). Finally, even though $N$. cheilancristrotus metacestodes have been reported several times, there are no detailed data on seasonality of $N$. cheilancristrotus metacestodes in their hosts (see Chubb 1982 for review).

During a comparative study on the helminths of fishes from the Oder River (Germany/Poland) carried out from May 1993 to April 1995, and aimed to get further information on the ecology of fish helminths (Pietrock 1998), numerous N. cheilancristrotus meta-

Address for correspondence: M. Pietrock, St. Lawrence Center, 105 McGill Street, 7th floor, Montreal, Quebec H2Y 2E7, Canada.

Phone: ++514 496 5024; Fax: ++514 496 7398; E-mail: michael.pietrock@ec.gc.ca 
cestodes were found in the intestine of blue bream, Abramis ballerus (L.). This material enabled us to evaluate morphometrics of the parasite and to study seasonal patterns in its occurrence to broaden the knowledge of variability of taxonomically important features and seasonal dynamics of this cyclophyllidean cestode in its second intermediate host. Results of these observations are presented in this paper.

\section{MATERIALS AND METHODS}

Blue bream Abramis ballerus (Table 1) were collected from the Oder River between the river-km 695-699, i.e. near the town of Schwedt, Germany. Fish were sampled using gill and bow nets and seines at monthly intervals from May 1993 to April 1995 except December 1993, and January and February 1994 when fishing was impossible due to climatic conditions. At the sampling site, the river is $200-300 \mathrm{~m}$ wide, 3-5 $\mathrm{m}$ deep and is characterised as eutrophic. The bottom consists of sand and mud and is polluted by heavy metals (Meinelt et al. 1997).

A total of 633 fish were collected, ranging in age from 2+ to $16+$ years; most $(97 \%)$ were age $8+$ to $12+$. Age of fish was determined by scale examination. After capture, the fish were transported alive to the laboratory and dissected within 48 hours. After the fish were killed, their intestinal tracts were removed and slit longitudinally. The metacestodes found were counted and separated into $0.68 \%$ saline. Prevalence, intensity and mean intensity were used according to Bush et al. (1997).

Metacestodes used for morphometrical evaluation were cleaned in saline and fixed in hot neutral buffered $4 \%$ formaldehyde solution. Fixed specimens were covered by a coverslip as a wet mount and the following characters were measured: total body length, maximum body width, diameter of suckers, total length of rostellar hooks, length of handle, blade and guard (see Bona 1975)

\section{RESULTS}

\section{Morphometrics}

The body length and width of metacestodes examined varied considerably (Table 2 ). In contrast to this, the size of sclerotised parts showed minor variations only. Dimensions of metacestodes, including arithmetical mean, standard deviation and range (minimum-maximum) are presented in detail in Table 2.

\section{Seasonal occurrence}

Metacestodes of $N$. cheilancristrotus were found in all monthly samples of blue bream with the exception of May 1993, and July and August 1994. A total of 172 fish $(=27 \%)$ were infected. A survey of prevalence, intensity and mean intensity of $N$. cheilancristrotus infection in individual month samples is given in Table 1 and Fig. 1. The monthly prevalences varied throughout the period of investigation but showed distinct peaks in spring (March-June), and late autumn and early winter (November-December) (Fig. 1). The highest prevalence was noted in November 1994, when $55 \%$ of blue bream examined were infected. The course of mean intensity of infection resembled that of prevalence. The monthly mean intensity of infection ranged from 1.2 to 9.8 (Fig. 1); the maximum number in any fish was 56 worms (November 1994, Table 1).

\section{DISCUSSION}

Metacestodes of Neogryporhynchus cheilancristrotus are common intestinal parasites of blue bream from the Oder River where they also infect bream Abramis brama (L.), white bream A. bjoerkna (L.) and roach Rutilus rutilus (L.) (Pietrock et al. 1999). Neogryporhynchus cheilancristrotus metacestodes have been reported recently e.g. from the Czech Republic, Iraq, Poland and the former USSR (Kozicka 1971, Willomitzer 1980, Moravec 1985, Ali et al. 1987, Dubinina 1987, Scholz 1989). Despite the relatively frequent findings of $N$. cheilancristrotus metacestodes and other dilepidid tapeworm larvae, problems in their specific identification persist. Although the size of the muscular parts of the parasite is affected by fixing, staining and conservation, sclerotised parts such as the rostellar hooks are relatively unaffected by handling and are thus widely used for determination of dilepidid tapeworms. The total length of both large and small rostellar hooks of $N$. cheilancristrotus metacestodes found in blue bream from the Oder River agrees with most of the previously published measurements (Table 3 ). Slight differences in the total length of hooks may be attributed to gradual growth of hooks during larval development, as assumed by Baer and Bona (1960). The assumption of these authors has been supported by drawings of Jarecka (1970) and Kozicka (1971) who figured that rostellar hooks undergo changes in shape and size during development.

Distinct differences in size of hooks, however, exist between data of most authors and those described by Dubinina (1987) who recorded considerably larger hooks in N. cheilancristrotus (Table 3). Additionally, she also referred to a fourth dilepidid tapeworm larva occurring in fishes, namely Gryporhynchus pusillus Nordmann, 1832. For this species, she reported rostellar hooks being 40-60 $\mu \mathrm{m}$ (large ones) and 20-30 $\mu \mathrm{m}$ (smaller ones) long. It may be necessary to re-examine specimens studied by Dubinina (1987). It is possible that she based her conclusions on published data without examination of voucher specimens. Until a thorough examination of material of dilepidid metacestodes from the former USSR, referred to as $N$. cheilancristrotus and G. pusillus, is made to confirm existence of two valid species, all these findings are considered by the present authors to relate to only single taxon, N. cheilancristrotus. 
Table 1. Occurrence of Neogryporhynchus cheilancristrotus metacestodes in Abramis ballerus from the Oder River between May 1993 and April 1995.

\begin{tabular}{|c|c|c|c|c|}
\hline \multirow{3}{*}{ Year and month } & \multirow{3}{*}{$\begin{array}{l}\text { No. of blue } \\
\text { bream } \\
\text { examined }\end{array}$} & \multicolumn{3}{|c|}{ Infection } \\
\hline & & \multirow{2}{*}{ Prevalence $(\%)$} & \multicolumn{2}{|c|}{ Intensity } \\
\hline & & & Mean ( \pm S.D.) & Range \\
\hline \multicolumn{5}{|l|}{1993} \\
\hline May & 5 & 0 & - & - \\
\hline June & 42 & 29 & $5.1(5.8)$ & $1-23$ \\
\hline July & 40 & 38 & $2.6(1.7)$ & $1-7$ \\
\hline August & 57 & 7 & $2.7(2.2)$ & $1-6$ \\
\hline September & 33 & 24 & $1.8(1.0)$ & $1-4$ \\
\hline October & 45 & 29 & $1.8(1.2)$ & $1-5$ \\
\hline November & 9 & 44 & $3.0(1.4)$ & $1-5$ \\
\hline December & - & - & - & - \\
\hline \multicolumn{5}{|l|}{1994} \\
\hline January & - & - & - & - \\
\hline February & - & - & - & - \\
\hline March & 48 & 33 & $9.8(12.2)$ & $2-51$ \\
\hline April & 43 & 30 & $5.5(4.8)$ & $1-19$ \\
\hline May & 43 & 23 & $6.2(5.8)$ & $2-17$ \\
\hline June & 19 & 37 & $1.4(0.7)$ & $1-3$ \\
\hline July & 4 & 0 & - & - \\
\hline August & 46 & 0 & - & - \\
\hline September & 33 & 12 & $1.2(0.5)$ & $1-2$ \\
\hline October & 18 & 6 & $6.0(0)$ & 6 \\
\hline November & 31 & 55 & $7.6(13.0)$ & $1-56$ \\
\hline December & 45 & 49 & $4.2(6.6)$ & $1-31$ \\
\hline 1995 & & & & \\
\hline January & 15 & 27 & $1.5(0.5)$ & $1-2$ \\
\hline February & 15 & 27 & $7.7(7.2)$ & $1-15$ \\
\hline March & 11 & 45 & $2.6(1.1)$ & $1-4$ \\
\hline April & 31 & 42 & $6.3(9.2)$ & $1-33$ \\
\hline
\end{tabular}

Table 2. Dimensions of Neogryporhynchus cheilancristrotus metacestodes ( $\mathrm{n}=47$ worms, 210 large and 190 small hooks; all measurements in micrometres).

\begin{tabular}{|l|c|c|c|}
\hline & Arithmetical mean & Standard deviation & Range \\
\hline Total body length & 244.4 & 43.2 & $182.0-357.0$ \\
Maximum body width & 119.0 & 30.2 & $79.0-193.0$ \\
Diameter of suckers & 54.6 & 3.0 & $49.0-59.0$ \\
Large hooks & & & \\
$\quad$ Total length & 52.4 & 2.2 & $49.0-57.0$ \\
Blade & 33.9 & 1.1 & $31.3-35.2$ \\
Handle & 19.0 & 1.1 & $17.6-22.5$ \\
Guard & 8.6 & 1.1 & $6.8-9.8$ \\
Small hooks & & & \\
Total length & 37.6 & 1.9 & $34.3-40.0$ \\
Blade & 21.3 & 1.2 & $19.6-23.5$ \\
Handle & 16.9 & 1.2 & $14.7-18.6$ \\
Guard & 3.9 & 0.3 & $3.4-4.9$ \\
\hline
\end{tabular}

The occurrence of $N$. cheilancristrotus metacestodes in more than a quarter of blue bream examined shows that this helminth species is widespread in fish from the Oder River. However, although larval tapeworms have been present in their second intermediate host at any season, considerable monthly variations in occurrence were noted. Nevertheless, two periods of increased prevalences and mean intensities of infection were noted: spring, and late autumn and early winter. Obviously, during these periods, improved conditions exist for transmission of larval parasite stages from first to second intermediate host when compared with other 


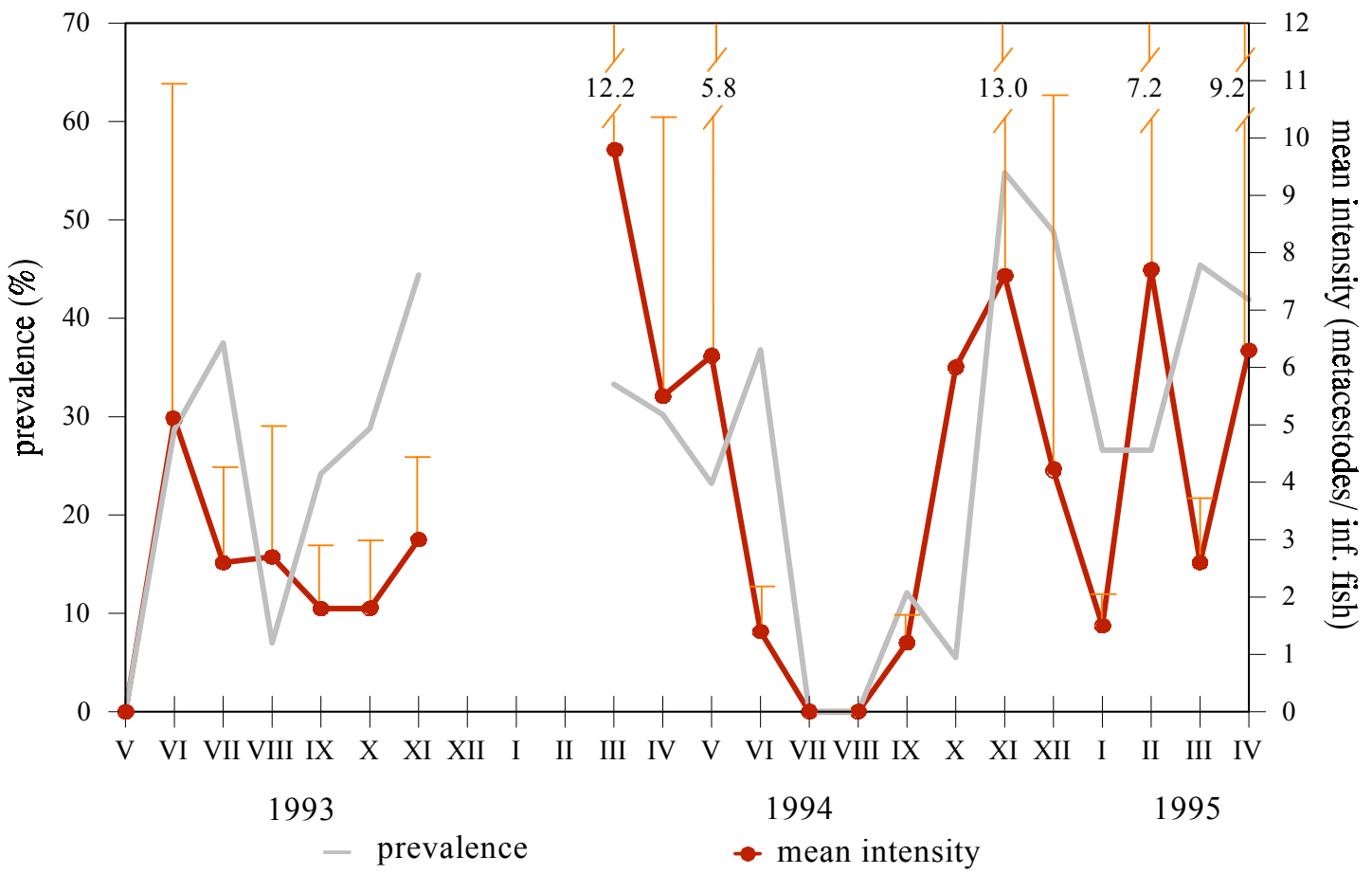

Fig. 1. Prevalence and mean intensity (mean, standard deviation) of infection of Abramis ballerus from the Oder River with metacestodes of Neogryporhynchus cheilancristrotus between May 1993 and April 1995 (no fish sampled from December 1993 to February 1994).

months. Mesocyclops oithonoides, till now the only known first intermediate host of $N$. cheilancristrotus (Jarecka 1970), is a common copepod of the summer zooplankton communities (Kiefer 1978, Lacroix and Lescher-Moutoué 1984). According to Frenzel (1977), studying the population dynamics of $M$. oithonoides, population maxima of this copepod occur in April, July and late October, which corresponds with observed increased prevalences of blue bream infection from the Oder River. Reduced infection level during summer may reflect changes in feeding behaviour of a part of blue bream population but also other factors related to ecology of intermediate hosts, like water temperature or photoperiod etc., may be involved (Kennedy 1975).

Table 3. Length of rostellar hooks of Neogryporhynchus cheilancristrotus metacestodes reported by different authors (all measurements in micrometres).

\begin{tabular}{|c|c|l|}
\hline Large hooks & Small hooks & \multicolumn{1}{|c|}{ References } \\
\hline 52 & $34-36$ & Wagener (1856), according \\
$54-57$ & 27 & to Baer and Bona (1960) \\
53 & 39 & Dubinin (1952) \\
$58-61$ & $30-36$ & Mozicka (1959) \\
$49-54$ & $36-39$ & Kozicka (1970) \\
60 & 40 & Ali et al. (1987) \\
$60-80$ & $40-50$ & Dubinina (1987) \\
$51-57$ & $36-39$ & Scholz (1989) \\
$49-57$ & $34-40$ & present study \\
\hline
\end{tabular}

Long-term investigations on $N$. cheilancristrotus infections of fish are quite scarce and most reports on $N$. cheilancristrotus infections of fish are faunistic findings only or give no detailed information on seasonal occurrence of this parasite (Molnár 1970, Kozicka 1971, Ali et al. 1987). Ivasik (1953), studying the parasite infection of carp (Cyprinus carpio) from 24 fish farms in the western part of Ukraine, recorded Gryporhynchus sp. (most probably N. cheilancristrotus) infections of fish throughout the year with the highest prevalence of $3.6 \%$ during summer. Moravec (1985) found single specimens (total prevalence 2.6\%) in tench (Tinca tinca) only in cold months (between November and February). Thus, the results of these authors indicate that new infections of fish are possible and take place at any season. Further studies on e.g. life-span of metacestodes in fish or range of first intermediate hosts are required to explain the parasite's presence or absence during a particular season. The differences in prevalence of infection of fish from different waters are due to the different ecological conditions of the habitats such as the occurrence of intermediate and final hosts, and nutritional habits of the fish hosts investigated as well.

Long-term studies on other dilepidid infections of fish revealed a similar course of infection like that in blue bream from the Oder River. Jara and Olech (1964) found the highest prevalence $(100 \%)$ of Valipora campylancristrota (Wedl, 1855) infection in juvenile 
carp, C. carpio, in April, followed by a stepwise drop in prevalence until December, indicating that most of the fish become infected during spring, too. However, ecological strategies may account for differences in the seasonal infections of the various dilepidid tapeworm species.

Acknowledgements. Our thanks are due to H. Zahn, M. Teubner and W. Lücke from the fishing cooperative of Schwedt for collecting the fish and willingly helping us. Our gratitude is also due to A. Stüber, D. Thoms and U. Klemm of the Institute of Freshwater Ecology and Inland Fisheries, Berlin for their assistance in collecting and examining the fish and providing technical support. This study was partly supported by the grant No. 40095/705.6.133 from the German association "Stifterverband für die Deutsche Wissenschaft" to M.P. and by the grant No. 206/98/0591 from the Grant Agency of the Czech Republic to T.S. and the project No. K 2000601 of the Academy of Sciences of the Czech Republic.

\section{REFERENCES}

ALI N.M., AL-JAFERY A.R., ABDUL-AMEER K.N. 1987 Parasitic fauna of freshwater fishes in Diyala River, Iraq. J. Biol. Sci. Res. 18: 163-181.

BAER J.G., BONA F. 1960: Révision des cestodes Dilepididae Fuhrm., 1907 des Ardéiformes. Note préliminaire. Boll. Inst. Mus. Zool. Univ. Torino 6: 1-98.

BONA F. 1975: Etude critique et taxonomique des Dilepididae Fuhrm., 1907 (Cestoda) parasites des Ciconiiformes. Considérations sur la specificité et la spéciation. Monit. Zool. Ital. Monogr. N.S. Monografia 1, 750 pp.

BUSH A.O., LAFFERTY K.D., LOTZ J.M., SHOSTAK A.W. 1997: Parasitology meets ecology on its own terms: Margolis et al. revisited. J. Parasitol. 83: 575-583.

CHUBB J.C. 1982: Seasonal occurrence of helminths in freshwater fishes. Part IV. Adult Cestoda, Nematoda and Acanthocephala. Adv. Parasitol. 20: 1-292.

CHUBB J.C., POOL D.W., VELTKAMP C.J. 1987: A key to the species of cestodes (tapeworms) parasitic in British and Irish freshwater fishes. J. Fish Biol. 31: 517-543.

DUBININ V.B. 1952: Larval fauna of parasitic worms of vertebrates from the Volga delta. Parazitol. Sb. 14: 213265. (In Russian.)

DUBININA M.N. 1987: Class tapeworms - Cestoda Rudolphi, 1808. In: O.N. Bauer (Ed.), Key to the Parasites of Freshwater Fish of the USSR. Vol. 3. Nauka, Leningrad, pp. 5-76. (In Russian.)

FRENZEL P. 1977: Zur Bionomie von Thermocyclops oithonoides (G.O. Sars). Arch. Hydrobiol. 80: 108-130.

IVASIK V.M. 1953: Carp parasites and diseases they cause in fish farms in the western districts of the Ukrainian S.S.R. Trudy Nauchno-Issledovatel'skogo Instituta Prudovogo i Ozernogo Rybnogo Chozyaistva Ukrainskoi SSR 9: 85-122. (In Russian.)

JARA Z., OLECH W. 1964: Dynamics of cysticercus Dilepis campylancristrotae (Aubert) infection of carp. Wiad. Parazytol. 10: 513-520.

JARECKA L. 1970: On the life-cycles of Paradilepis scolecina (Rud., 1819) Hsü, 1935, and Neogryporhynchus cheilancristrotus (Wedl, 1855) Baer and Bona, 1958-1960 (Cestoda-Dilepididae). Bull. Acad. Pol. Sci. 18: 159-163.

JARECKA L. 1975: Ontogeny and evolution of cestodes. Acta Parasitol. Pol. 23: 93-114.

KENNEDY C.R. 1975: Ecological Animal Parasitology. Blackwell Scientific Publications, Oxford, London, Edinburgh, Melbourne, 163 pp.
KIEFER F. 1978: Freilebende Copepoda. In: H.-J. Elster and W. Ohle (Eds.), Die Binnengewässer. Bd. 26, 2. Teil. E. Schweizerbart'sche Verlagsbuchhandlung, Stuttgart, pp. 1367.

KOZICKA J. 1959: Parasites of fishes of Drużno Lake. Acta Parasitol. Pol. 7: 1-72.

KOZICKA J. 1971: Cestode larvae of the family Dilepididae Fuhrmann, 1907 parasitizing freshwater fish in Poland. Acta Parasitol. Pol. 19: 81-93.

LACROIX G., LESCHER-MOUTOUÉ F. 1984: Diapause des Cyclopoides d'un écosystème lacustre peu profond (Lac de Créteil, France). Ann. Limnol. 20: 183-192.

MEINELT T., KRÜGER R., PIETROCK M., STÜBER A., OSTEN R., STEINBERG C. 1997: Metal loads in sediments, pike (Esox lucius) and bream (Abramis brama) tissues in the River Oder (Germany/Poland). Arch. Naturschutz Landschaftsforsch. 36: 1-9.

MOLNÁR K. 1970: Beiträge zur Kenntnis der Fischparasitenfauna Ungarns VI. Cestoda, Nematoda, Acanthocephala, Hirudinea. Parasitol. Hung. 3: 51-76.

MORAVEC F. 1985: Occurrence of the endoparasitic helminths in tench (Tinca tinca) from the Mácha Lake fishpond system. Věst. Čs. Spol. Zool. 49: 32-50.

PIETROCK M. 1998: Faunistisch-ökologische Untersuchungen zum Endohelminthenbefall von Zope (Abramis ballerus) und Kaulbarsch (Gymnocephalus cernuus) aus der Unteren Oder. Verlag Wissenschaft und Technik, Berlin, 229 pp.

PIETROCK M., MEINELT T., KRÜGER R. 1999: Schadstoffbelastung und Fischgesundheit im Nationalpark "Unteres Odertal”. In: W. Dohle, R. Bornkamm and G. Weigmann (Eds.), Das Untere Odertal. E. Schweizer-bart'sche Verlagsbuchhandlung (Nägele und Obermiller), Stuttgart, pp. 417-430.

SCHOLZ T. 1989: Amphilinida and Cestoda, parasites of fish in Czechoslovakia. Acta Sci. Nat. Brno 23, No. 4, 56 pp.

WEDL C. 1855: Charakteristik mehrerer größtentheils neuer Tänien. Sitzungsber. Akad. Wiss. Wien, Math.-Naturwiss. Cl. 18: 5-27.

WILLOMITZER J. 1980: Seasonal dynamics of parasitoses in grasscarp (Ctenopharyngodon idella) fry and fingerlings. Acta Vet. Brno 49: 269-277.

Accepted 2 February 2000 